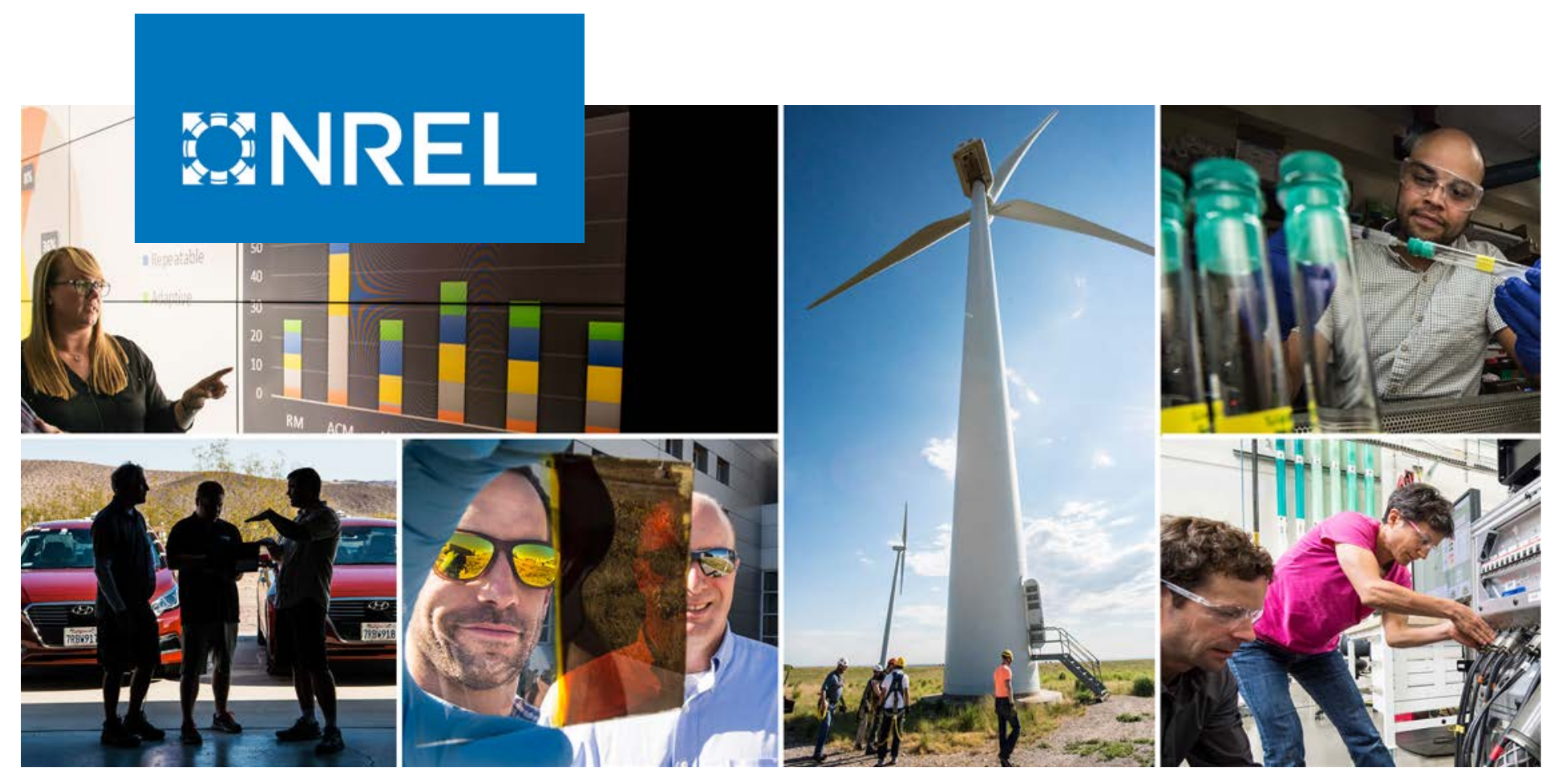

\title{
Validation of SolarWorld Modules at the NREL Regional Test Center Site
}

\section{Cooperative Research and Development Final Report}

\section{CRADA Number: CRD-15-595}

NREL Technical Contact: Chris Deline

NREL is a national laboratory of the U.S. Department of Energy Office of Energy Efficiency \& Renewable Energy

Operated by the Alliance for Sustainable Energy, LLC

This report is available at no cost from the National Renewable Energy Laboratory (NREL) at www.nrel.gov/publications.
Technical Report

NREL/TP-5K00-77089

June 2020 


\title{
GHREL
}

\section{Validation of SolarWorld Modules at the NREL Regional Test Center Site}

\author{
Cooperative Research and Development Final \\ Report
}

\section{CRADA Number: CRD-15-595}

NREL Technical Contact: Chris Deline

\section{Suggested Citation}

Deline, Chris. 2020. Validation of SolarWorld Modules at the NREL Regional Test Center Site: Cooperative Research and Development Final Report, CRADA Number CRD-15595. Golden, CO: National Renewable Energy Laboratory. NREL/TP-5K00-77089.

https://www.nrel.gov/docs/fy20osti/77089.pdf.

NREL is a national laboratory of the U.S. Department of Energy Office of Energy Efficiency \& Renewable Energy Operated by the Alliance for Sustainable Energy, LLC

This report is available at no cost from the National Renewable Energy Laboratory (NREL) at www.nrel.gov/publications.

Contract No. DE-AC36-08GO28308
Technical Report NREL/TP-5K00-77089 June 2020

National Renewable Energy Laboratory 15013 Denver West Parkway Golden, CO 80401 303-275-3000 • www.nrel.gov 


\section{NOTICE}

This work was authored by the National Renewable Energy Laboratory, operated by Alliance for Sustainable Energy, LLC, for the U.S. Department of Energy (DOE) under Contract No. DE-AC36-08GO28308. Funding provided by U.S. Department of Energy Office of Energy Efficiency and Renewable Energy Solar Energy Technologies Office. The views expressed herein do not necessarily represent the views of the DOE or the U.S. Government.

This work was prepared as an account of work sponsored by an agency of the United States Government. Neither the United States Government nor any agency thereof, nor any of their employees, nor any of their contractors, subcontractors or their employees, makes any warranty, express or implied, or assumes any legal liability or responsibility for the accuracy, completeness, or any third party's use or the results of such use of any information, apparatus, product, or process disclosed, or represents that its use would not infringe privately owned rights. Reference herein to any specific commercial product, process, or service by trade name, trademark, manufacturer, or otherwise, does not necessarily constitute or imply its endorsement, recommendation, or favoring by the United States Government or any agency thereof or its contractors or subcontractors. The views and opinions of authors expressed herein do not necessarily state or reflect those of the United States Government or any agency thereof, its contractors or subcontractors.

This report is available at no cost from the National Renewable Energy Laboratory (NREL) at www.nrel.gov/publications.

U.S. Department of Energy (DOE) reports produced after 1991 and a growing number of pre-1991 documents are available free via www.OSTI.gov.

Cover Photos by Dennis Schroeder: (clockwise, left to right) NREL 51934, NREL 45897, NREL 42160, NREL 45891, NREL 48097, NREL 46526.

NREL prints on paper that contains recycled content. 


\section{Cooperative Research and Development Final Report}

\section{Report Date: May 11, 2020}

In accordance with requirements set forth in the terms of the CRADA agreement, this document is the final CRADA report, including a list of subject inventions, to be forwarded to the DOE Office of Scientific and Technical Information as part of the commitment to the public to demonstrate results of federally funded research.

Parties to the Agreement: SolarWorld Americas, Inc. (ceased operations in 2019 due to acquisition by SunPower, Inc. in 2018)

CRADA Number: CRD-15-595

CRADA Title: Validation of SolarWorld Modules at the NREL Regional Test Center Site

Joint Work Statement Funding Table showing DOE commitment:

\begin{tabular}{|c|c|}
\hline Estimated Costs & $\begin{array}{c}\text { NREL Shared Resources } \\
\text { a/k/a Government In-Kind }\end{array}$ \\
\hline Year 1 & $\$ 120,000.00$ \\
Year 2, Modification \#2 & $\$ 20,000.00$ \\
Year 3, Modification \#3 \& 4 & $\$ 24,000.00$ \\
\hline TOTALS & $\$ 164,000.00$ \\
\hline
\end{tabular}

\section{Abstract of CRADA Work:}

SolarWorld and the National Renewable Energy Laboratory (NREL) are entering into a cooperative research and development agreement (CRADA) in order to perform validation testing of SolarWorld's Photovoltaic (PV) modules through the Department of Energy (DOE) Regional Test Center (RTC) program. This CRADA describes testing activities conducted specifically at the NREL-managed Colorado RTC site.

\section{Summary of Research Results:}

The Regional Test Centers conducted field trials to quantify the performance of SolarWorld's silicon PV modules including monosilicon $290 \mathrm{~W} 5$ bus bar modules with glass-backsheet construction; high-efficiency PERC glass-glass modules at $280 \mathrm{~W}$; multicrystalline Si modules at 260W per panel, and bifacial PERC modules, glass-glass construction.

Four specific tasks were conducted, as described below: Design, Construction, Data Acquisition and Analysis, and Final Report. Through the process of the project, a custom PV installation was designed and installed for SolarWorld, and five reports issued including a final close-out report. 
Based on the first 3 years of system performance (Nov 2016 - Dec 2019), the following characteristics stand out:

- Measured performance was within 3\%-5\% of modeled expectation for three module types (290W mono, 280W PERC and 280W bifacial PERC)

- The $260 \mathrm{~W}$ monocrystalline string operated at $8 \%$ below expectation.

- Bifacial response of the bifacial PERC string was 3.4\% above the monofacial PERC string, which is slightly below expectation based on measured rear-side irradiance (should be $4.4 \%$ bifacial gain).

- An extended outage in the NREL field was experienced from October-December 2018 mandated by the utility (Xcel energy) which may have influenced final results.

\section{Task 1: Design}

In this task, NREL worked with SolarWorld to develop a technical validation plan. This document went through multiple revisions starting March 2015 and was issued in a final version on 10 October 2015. This document was the controlling document for subsequent validation testing and was largely adhered to.

Initial project technical design was initiated April 2015 to establish technical scope and requirements for the partner. See Table 1 here and Figures 1 and 2 in Task 2.

Table 1. System summary information.

\begin{tabular}{|l|l|}
\hline System parameter & System Spec \\
\hline Array tilt angle & $30^{\circ}$ \\
\hline Array azimuth: & $180^{\circ}(\mathrm{S})$ \\
\hline Altitude (ft) & 5790 \\
\hline Site Latitude & 39.7403 \\
\hline Site Longitude & 105.6217 \\
\hline
\end{tabular}

\begin{tabular}{|l|l|l|l|l|}
\hline Module Parameter & String 1 & String 2 & String 3 & String 4 \\
\hline Manufacturer & SolarWorld & SolarWorld & SolarWorld & SolarWorld \\
\hline Module Type & SW290 Mono & SW270 Duo & SW270 PERC & SW260 Poly \\
\hline Technology & mono-Si & PERC bifacial & PERC & Poly-Si \\
\hline No. of modules & 8 & 6 & 8 & 8 \\
\hline String power $(\mathrm{kW})$ & $2.32 \mathrm{~kW}$ & $1.62 \mathrm{~kW}$ & $2.16 \mathrm{~kW}$ & $2.08 \mathrm{~kW}$ \\
\hline Date of Installation & $11 / 3 / 2016$ & $11 / 3 / 2016$ & $11 / 3 / 2016$ & $11 / 3 / 2016$ \\
\hline Inverter & ABB PVI 6.0 & ABB PVI 6.0 & ABB PVI 6.0 & ABB PVI 6.0 \\
\hline MPPT channel & Inv1 MPPT1 & Inv1 MPPT2 & Inv2 MPPT1 & Inv2 MPPT2 \\
\hline
\end{tabular}




\section{Task 2: Construction}

Modules were initially received from SolarWorld on June-July 2016. Field installation of PV racking and initial module mounting occurred in October 2016. Data acquisition for the system was initiated on 11/3/2016. System data was confirmed good without any initial start-up errors.

The SolarWorld RTC installation consists of four PV module strings : SW 290 Monofacial, SW 270 Duo (bifacial), SW 270 Mono PERC and SW 260 Poly. Each string consists of eight modules apiece, except for the SW 270 Duo string, which consists of six modules. Two PVI-6K grid-tied PV inverters connect to two strings apiece.

Figure 1 shows the SolarWorld installation at NREL, with a schematic view shown in Figure 2. All four module types were installed at the same time, with system turn-on occurring November 3, 2016.

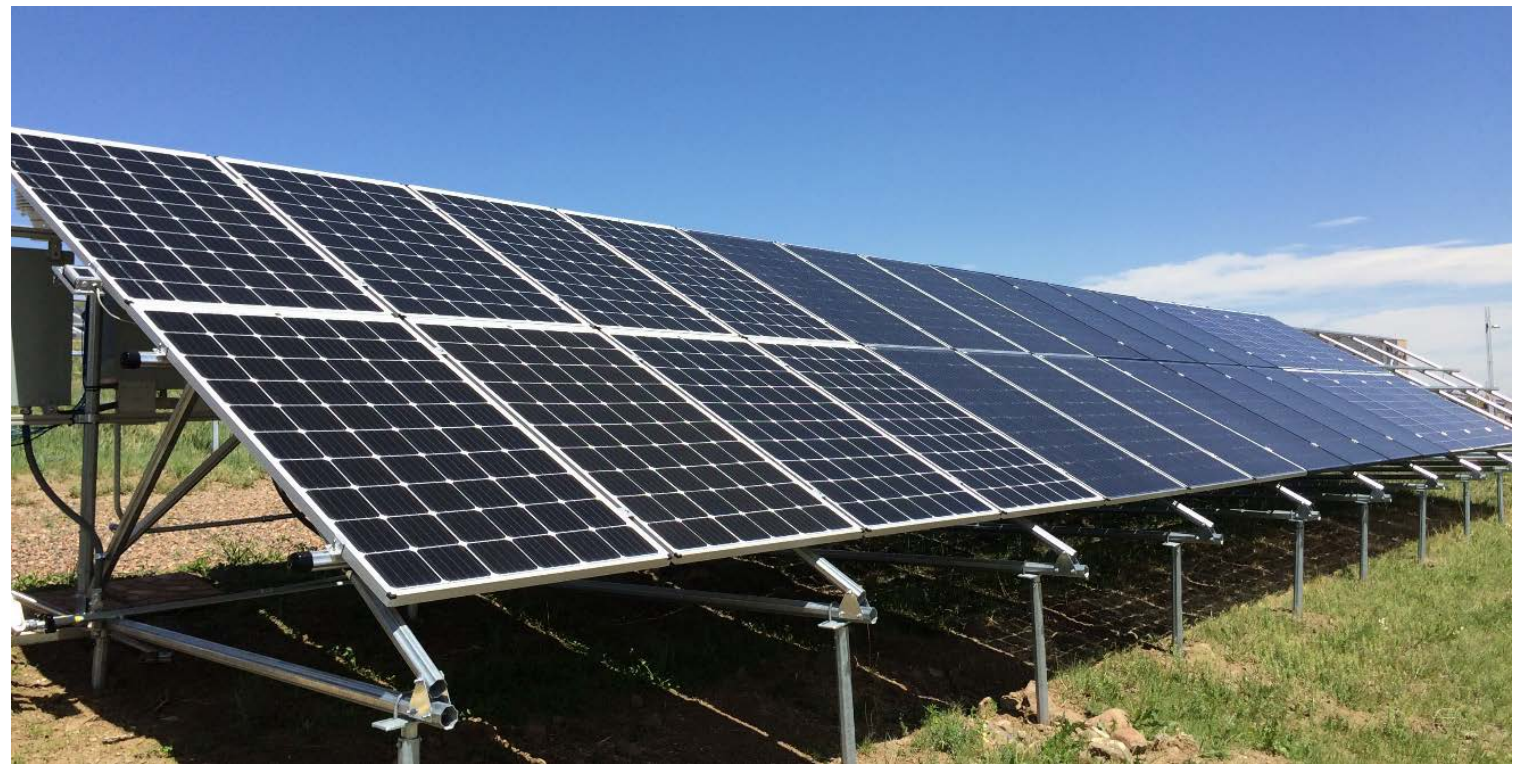

Figure 1: View of the SolarWorld installation at NREL.

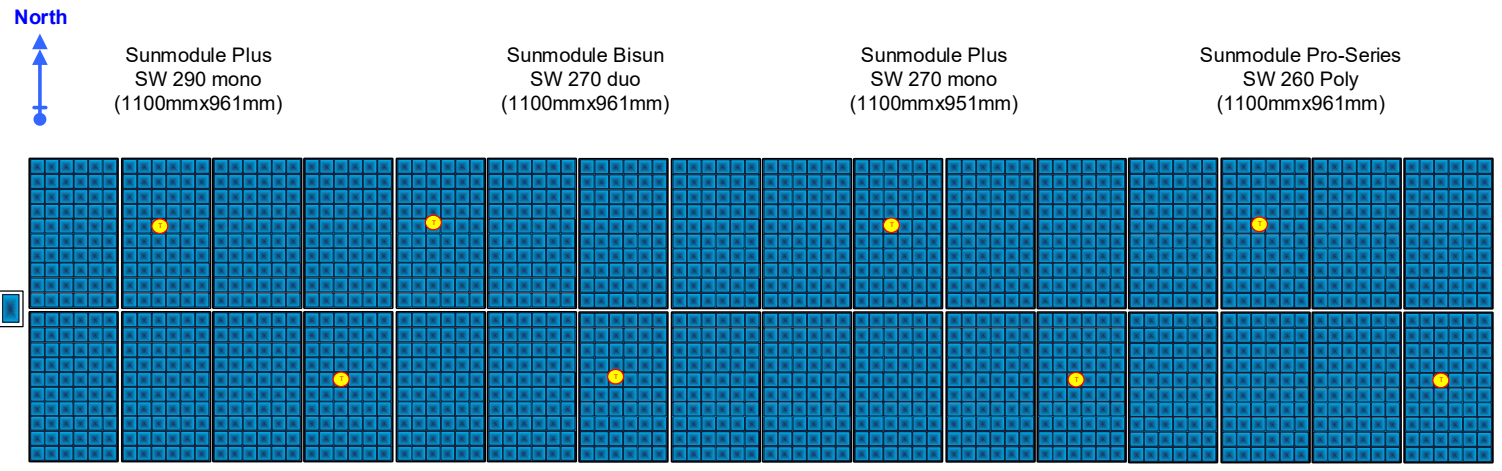

Front View

Figure 2: Module layout including mounting position of the forward-facing IMT reference cell, and module temperature measurements. A string with eight SW 290 Mono modules and a string with six SW 270 Duo modules are connected to the first PVI-6K string inverter. A string with eight SW 270 mono modules and a string with eight SW 260 Poly modules are connected to the second PVI$6 \mathrm{~K}$ string inverter. 


\section{Task 3: Data Acquisition and Analysis}

Field data was collected for the remainder of the project, and four test reports issued:

- 201705 NREL 6-month energy test report

- 201711 NREL 12 month energy test report

- 201808 NREL 18 month energy test report

- 201912 NREL final (36 month) energy test report

The raw performance data is considered Protected CRADA Information. Below are excerpts from a non-protected summary of the test procedure and some findings are presented below to describe data for the completed tasks.

\section{Energy analysis: IEC 61724-3}

\section{Test Boundary}

IEC 61724-3 is clear to require a definition of test boundary-i.e. which elements of the installation are inside or outside of the region of analysis. The inputs are typically defined by external weather conditions including global horizontal irradiance, wind speed and ambient temperature. The system outputs are usually defined to be AC energy delivered to the grid. In this case, because we are mainly interested in PV module relative performance, we can reduce model uncertainty by defining a system boundary closer to the PV strings. In this case, back-ofmodule temperature is measured, and plane-of-array irradiance is measured with a matched IMT reference cell. Output power is measured at the DC string level too. Monitoring equipment is detailed in Appendix A.

Other environmental conditions are uncontrolled - including ground albedo, natural snow/soiling and nearby shade obstructions. These factors will be described below. For the first three PV strings, proper data collection started November 3, 2016. This date is chosen for the start of the energy analysis.

\section{Data analysis}

Production data is averaged over 1-minute intervals, and filtered only for irradiance and DC power $>0$. Prior to filtering, data availability was assessed to be $92 \%$ from two outages. Inverter 2 which was connected to PERC and Poly strings had an outage from 1/15/18 through 1/30/18. An additional 98-day forced outage was also logged between 10/4/2018 and 1/10/2019 due to an interconnect agreement dispute and re-negotiation with the site utility Xcel Energy. This was resolved by installing required production metering and updating research PV and Energy Storage assets at the NREL Regional Test Center campus site. This totals 2251 hours of lost data and system de-energized time (modules were at open circuit) to the experiment period under consideration.

This outage is removed from subsequent monthly and cumulative PR and model comparison. Monthly kWh production for each string is shown in Figure 3. 


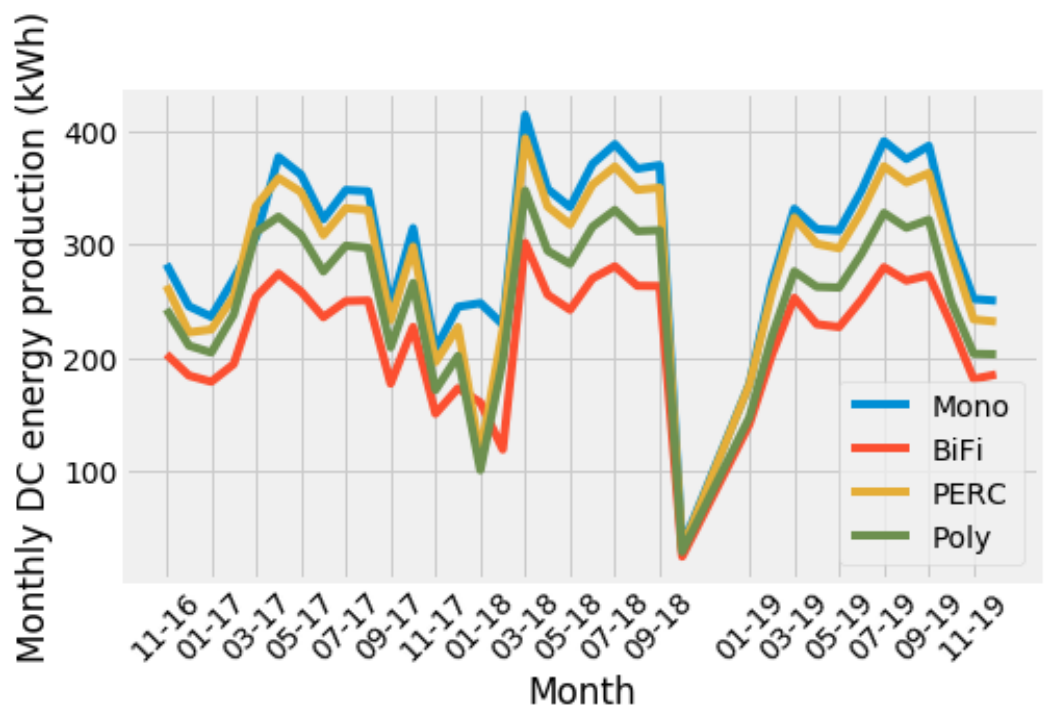

Figure 3: Monthly kWh production for the four SolarWorld strings. Note low performance in January 2018 for PERC and Poly strings due to a 2-week inverter outage.

\section{Further Analysis of Bifacial modules}

The main purpose of this test site is to evaluate the performance advantage of bifacial PV modules. We should first note that the field test site is not optimized for bifacial response. The ground below is relatively low - natural dirt and brush. Furthermore, although rear obstructions from back-mounted inverters were minimized, there is likely to be rear shading from racking and structural cross-members. This being said, we can assess the bifacial gain in energy for each month of our deployment according to:

$$
\begin{gathered}
B G_{E}=100 \% *\left(\frac{\sum P_{\text {bifacial }} / P_{m p}}{\sum P_{\text {monofacial }} / P_{m p}}\right) \\
\text { Bifaciality } \varphi=\frac{P_{m p, \text { rear }}}{P_{m p, \text { front }}}
\end{gathered}
$$

Here $P_{m p}$ is the measured single-sided power of each string from factory flash data, not nameplate rating, in order to more carefully account for the direct benefit of bifacial production.

On a cumulative basis, the SW 270 Duo bifacial module type produced $3.4 \%$ more energy than its monofacial peer (Figure 4). This was highest in the month of December, which experienced snow. In the context of the ability to capture available backside resource, this is about $1.2 \%$ less bifacial gain than expected, since the rear irradiance resource is on average only $7.6 \%$ of the front resource (Figure 5). This result is summarized in Table 5. The bifacial under-performance may be in part due to rack shading behind the bifacial modules, or non-uniform rear irradiance. 
Table 2: Bifacial gain for SW270 Duo bifacial modules

\begin{tabular}{|l|l|}
\hline & SW270 Duo Bifacial \\
\hline Bifaciality $\varphi$ (Eq. 4) & 0.6 \\
\hline Grear / Gfront (Fig. 8) & $7.4 \%$ \\
\hline BGE (expected) & $104.4 \%$ \\
\hline BGE $_{E}$ (measured) & $103.4 \%$ \\
\hline
\end{tabular}

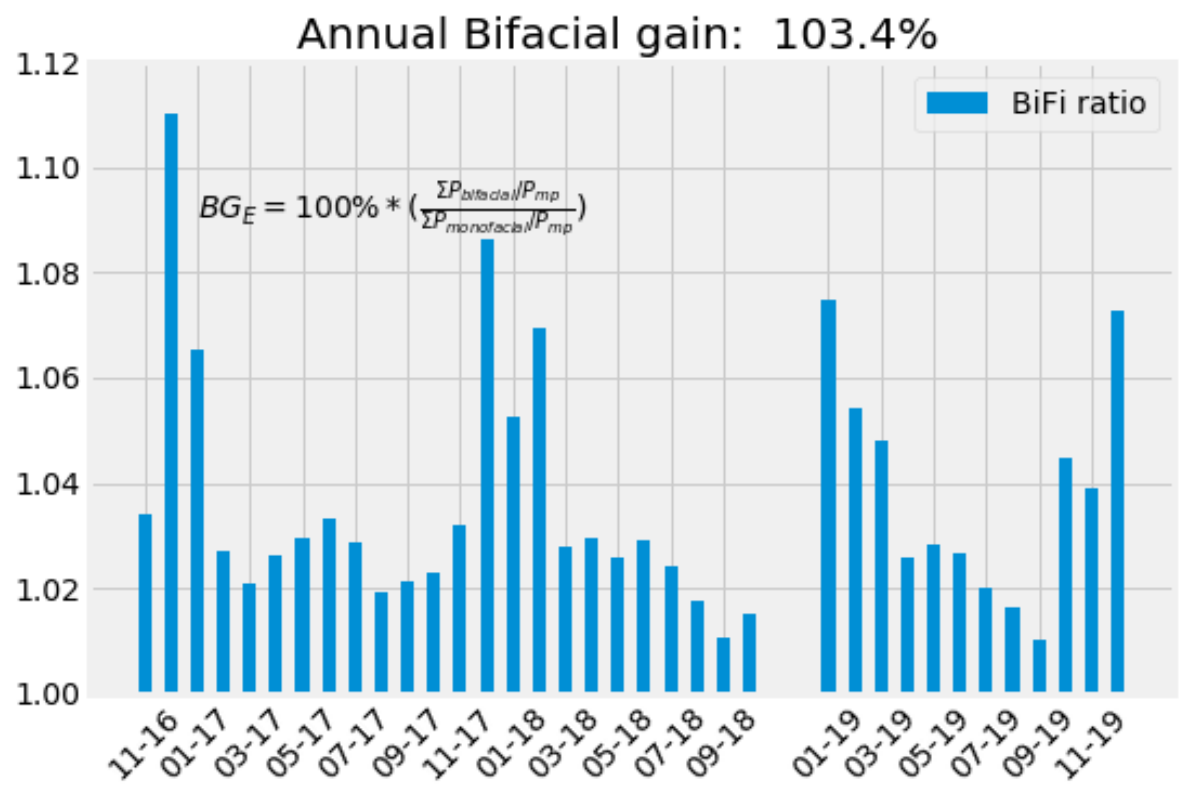

Figure 4: Bifacial energy gain for SolarWorld SW270 Duo bifacial modules deployed at the NREL RTC site.

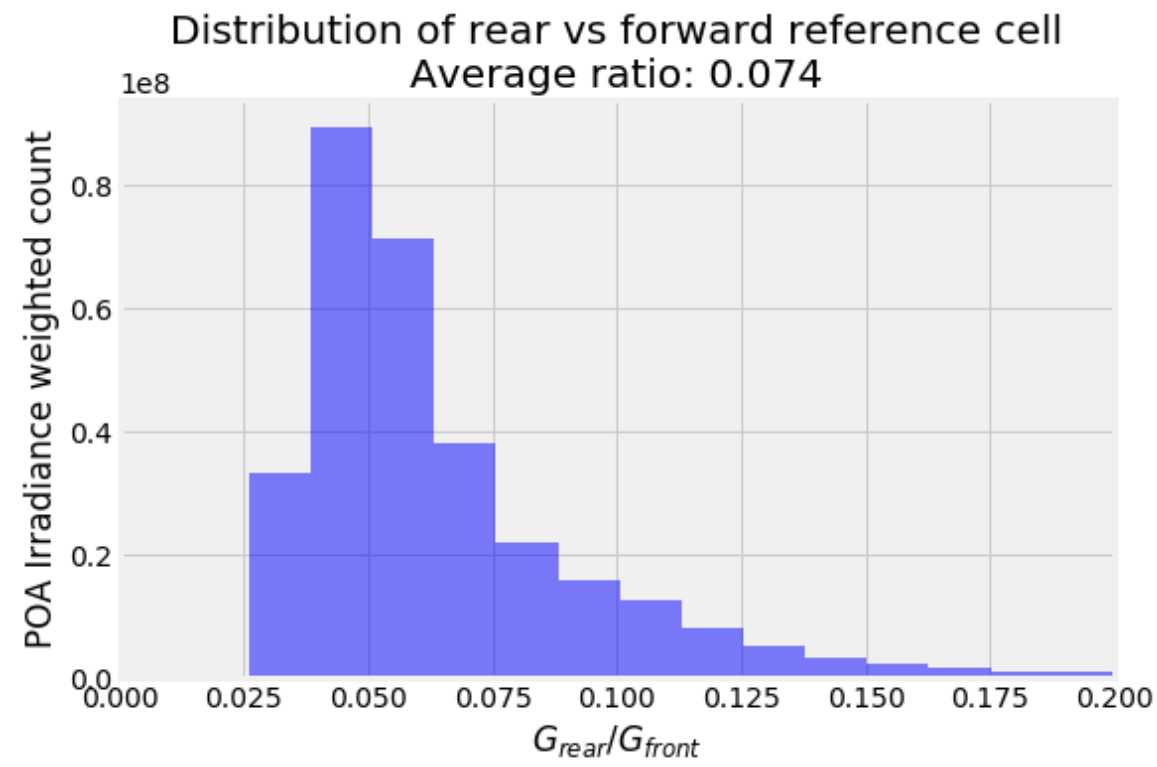

Figure 5: Distribution of $G_{\text {rear }} / G_{\text {front }}$ weighted by POA irradiance as measured at the NREL site. 


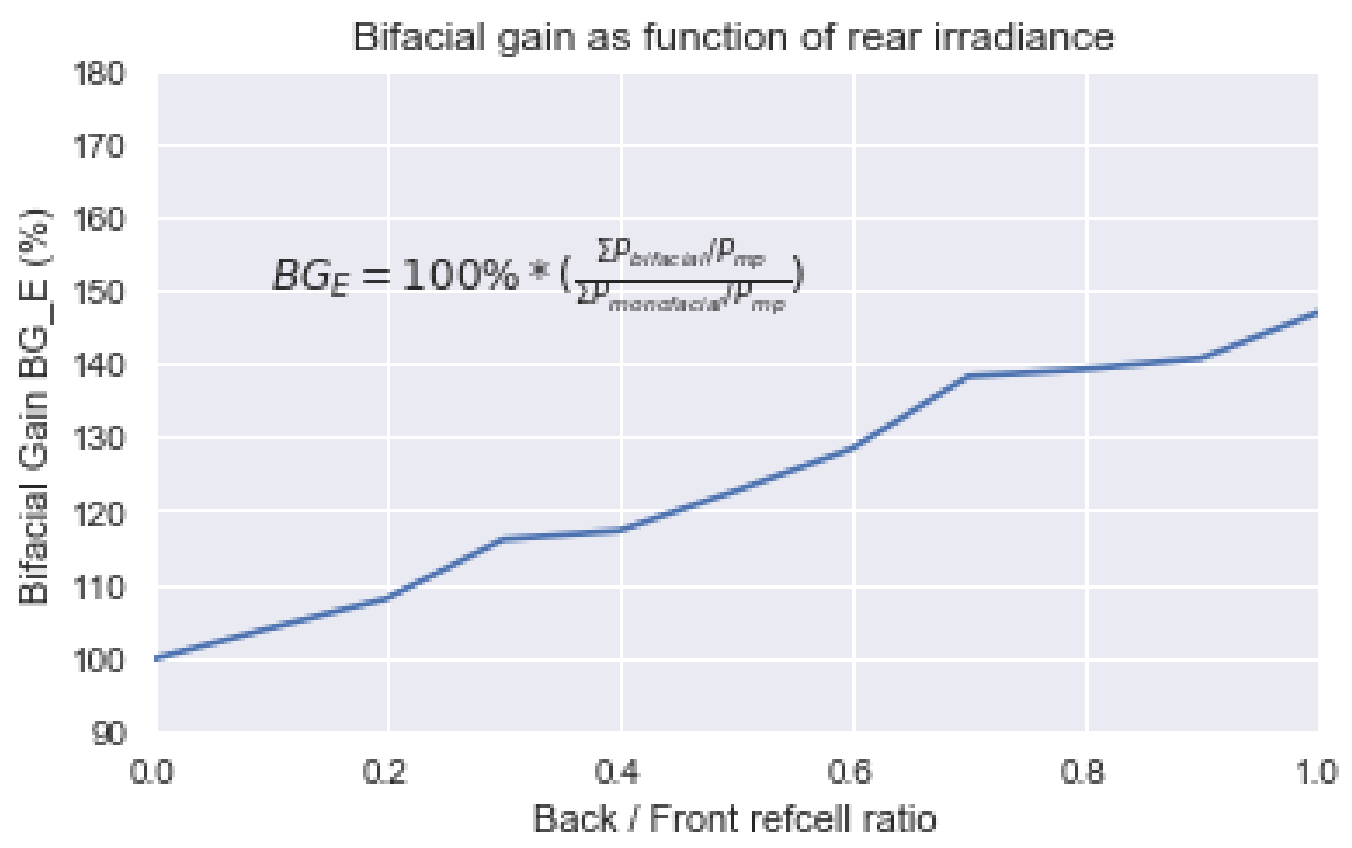

Figure 6: Bifacial gain as a function of rear-side irradiance.

Figure 6 also shows that the measured bifacial gain of these modules is relatively linear with respect to back-to-front irradiance ratio, therefore operation of these modules in a higher albedo environment is expected to increase bifacial energy production. According to Figure 8, for the majority of time available rear irradiance is around 0.074 , consequently $\mathrm{BG}_{\mathrm{E}}$ is correspondingly low on average.

\section{Task 4: Final Report}

The final CRADA report deliverable comprises this document.

\section{CRADA benefit to DOE, Participant, and US Taxpayer:}

Assists laboratory in achieving programmatic scope, adds new capability to the laboratory's core competencies and enhances the laboratory's core competencies.

\section{Value to Partner and US Manufacturing:}

The field test data collected provided valuable information and results that helped to establish performance capabilities of US-manufactured modules by SolarWorld Americas in 2016-2017. A serial defect in module connector leads identified in the field was also investigated at the NREL site, and helped to inform the manufacturer's warranty / recall strategy. In Oct 2018, market forces led to the sale / acquisition of SolarWorld Americas to SunPower Inc. The intellectual property being investigated at this site was not transferred to industry during this acquisition, and the CRADA partner ceased responsiveness and wound down operations in January 2019, thus exiting this CRADA. 


\section{Subject Inventions Listing:}

None

ROI \#:

None

Responsible Technical Contact at Alliance/NREL:

Chris Deline $\mid \underline{\text { chris.deline } @ \text {,nrel.gov }}$

Name and Email Address of POC at Company:

Eric Olson | Eric.Olson@SolarWorldUSA.com

DOE Program Office:

Office of Energy Efficiency and Renewable Energy (EERE), Solar Energy Technologies Office (SETO) 